\title{
THE EFFECT OF NITROGEN FERTILIZATION ON PRODUCTION AND QUALITATIVE PROPERTIES OF SOWN GRASSLANDS IN THE SYSTEM OF SUSTAINABLE PRODUCTION
}

\author{
Z. Bijelić, Z. Tomić, D. Ružić-Muslić
}

Institute for Animal Husbandry, Autoput 16, P. Box 23, 11080, Belgrade-Zemun, Republic of Serbia Corresponding author: zonesh@gmail.com Invited paper

Abstract: Nitrogen fixation in grass-leguminous mixtures is not sufficient to satisfy the nitrogen requirements of plants, therefore it is necessary to compensate this deficiency by nitrogen from mineral fertilizers. Objective of this study is to present the effect of $\mathrm{N}$ application in grass-leguminous mixtures on their production and qualitative properties, i.e. to give an answer to the question if application of nitrogen fertilizers results in the increase or decrease of yield, quality and changes in the structural composition of the grassland. $\mathrm{N}$ from mineral fertilizers, especially considerable amounts of nitrogen, changes the structural composition of grasslands - the share of leguminous plants decreases and share of grasses increases. Yield of dry matter increases with added nitrogen fertilizers. The amounts of nitrogen fertilizer which exceed the requirements of plants reduce the economical justification of fertilization and sometimes can have even opposite effect. Nitrogen fertilization increases the content of crude proteins and protein yield, whereas other quality parameters decrease or remain unchanged. Too much nitrogen in crops leads to nitrate accumulation in plants which is undesirable quality parameter.

Key words: grass-legume mixtures, $\mathrm{N}$ fertilization, production, quality

\section{Introduction}

In order to intensify the livestock production by introducing high yielding cattle and sheep breeds in production of milk and meat, it is necessary to provide sufficient quantities of roughage of high nutritional value. This can be achieved by introducing into production high yielding, high quality and stable forage grassland base adjusted to different exploitation methods: green, grazing and cutting, and conservation. In this way, the use of expensive concentrated food is avoided which lowers the production costs and contributes to its profitability. Alfalfa is perennial 
forage crop most present in animal nutrition, in the world as well as in Serbia. In addition to high yields, it is characterized by very good quality. In animal nutrition, it is used in various forms. In Serbia, it is mainly used as pure crop for preparation of hay or silage. It grows very well in grass-leguminous mixtures, especially in less favourable conditions for cultivation of alfalfa such as acid soils (Vučković, 2004). Cultivation in mixtures enables its use as more valuable forage plant by grazing, because it reduces the risk of bloat incidence. Also, more uniform crop yields are realized during the vegetation season, the incidence of weed plants is reduced, the water conservation in soil is improved as well as conservation of mineral matters. Due to nitrogen fixation ability and meeting of its nitrogen requirements, it also ensures nitrogen for associated species. Therefore, reduced application of nitrogen, in addition to more economically efficient production, also reduces the environment pollution, which has overall ecological and social significance.

The requirements of plants for $\mathrm{N}$ often cannot be fully satisfied through nitrogen fixation, especially in case of grass-leguminous mixtures, therefore this deficiency has to be compensated from mineral fertilizers.

Objective of this study is to present the effect of $\mathrm{N}$ fertilizer application in grass-leguminous mixtures on their production and qualitative characteristics, i.e. if the use of $\mathrm{N}$ fertilizers results in increase or decrease of yield, quality and change in the structural composition of the grassland.

\section{Botanical composition of grass-leguminous mixtures}

Grasslands as organized sets of plants have very changeable botanical composition depending on numerous biotic and abiotic factors (Alibegović-Grbić et al., 2005).

When growing grass-leguminous mixtures, special attention must be focused on selection of species included in the composition of mixtures, and this selection will primarily depend on the competitive ability of species, purpose of the grassland, exploitation method, agro-technical measures and agro-ecological conditions (Vučković, 2004). Compatibility of grasses and leguminous plants depends on morphological and physiological characteristics of the species, characteristics of given association, its interaction with applied agro-technical measures, but also climatic, edaphic and biological conditions under which the association is developing (Frame and Laidlaw, 1998). Many authors in their studies of the botanical composition of grass-leguminous mixtures have come to the conclusion that cocksfoot is the most compatible and the most competitive grass suitable for cultivation in mixture with strongly competitive leguminous plants, and in certain situations its competitiveness exceeds competitive abilities of leguminous plants and even suppresses them from the mixture (Mijatovic et al., 1983; Casler and Walgenbach, 1990; Jeranyama et al., 2005). Application of 
nitrogen fertilizers in mixtures reduces the nitrogen fixation abilities of leguminous plants which leads to diminishing of their competitive abilities and favours the grass component in the mixture (Nuttall et al., 1991). According to Berdahl et al. (2001; 2004), addition of nitrogen mineral fertilizers to alfalfa mixtures in the amount of $50 \mathrm{kgN} \mathrm{ha}^{-1}$ leads to significant increase of the share of grasses in total yield compared to alfalfa. Yolcu et al., (2010) have studied the effect of N fertilization in the amount of 0,60 and $120 \mathrm{~kg} \mathrm{ha}^{-1}$, on share of alfalfa in mixture with brome grass and concluded that the addition of increasing quantities of nitrogen caused gradual decrease of the share of alfalfa. Share of alfalfa in different fertilization treatments was $45.9,41.5$ and $37.5 \%$.

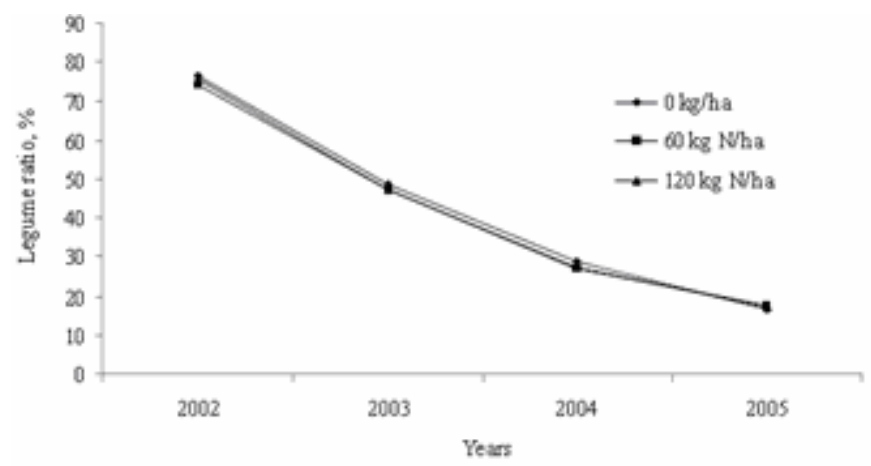

Graph 1. The effect of $\mathbf{N}$ fertilization on share of leguminous plants in mixture of alfalfa and brome grass (Source Yolcu et al., 2010))

In the study of the effect of $\mathrm{N}$ fertilization in the amounts of $0,70,140$ and $210 \mathrm{~kg} \mathrm{ha}^{-1}$ on changes of the botanical composition of alfalfa mixtures with cocksfoot, tall fescue and sainfoin, Nešić (2006), Nešić et al. (2007a), obtained similar results. Gradual adding of nitrogen in stated quantities resulted in gradual increase of share of grasses, and decrease of the share of leguminous plants in the mixture. In percentages, the share of leguminous plants depending on the fertilization treatment decreased from $71.5 \%$ in treatments without fertilization to $60.7 \%$ in treatment with $210 \mathrm{kgN} \mathrm{ha}^{-1}$ in the first research year and from $67.8 \%$ $(0 \mathrm{~N})$ to $57.5 \%(210 \mathrm{~N})$ in the second, and share of grasses increased from $29.9 \%(0 \mathrm{~N})$, to $38.8 \%(210 \mathrm{~N})$ in 2003 , i.e. from $40.9 \%(0 \mathrm{~N})$ to $52.0(210 \mathrm{~N})$ in 2004. 
Table 1. Share of groups of plants (\%) in total yield of grass-leguminous mixture depending on the $\mathrm{N}$ fertilization in years 2003 and 2004 (Source Nešić, 2006, Nešić et al.,2007a)

\begin{tabular}{|c|c|c|c|c|c|c|c|}
\hline \multirow{2}{*}{ Mixture } & \multirow{2}{*}{$\mathrm{N}$} & \multicolumn{3}{|c|}{2003} & \multicolumn{2}{|c|}{2004} & \\
\cline { 3 - 8 } & & $\mathrm{L}$ & $\mathrm{G}$ & $\mathrm{W}$ & $\mathrm{L}$ & $\mathrm{G}$ & $\mathrm{W}$ \\
\hline \multirow{4}{*}{ Grass-leguminous mixtures } & 0 & 71.5 & 29.9 & 6.0 & 67.8 & 40.9 & 1.5 \\
\hline & 70 & 64.4 & 38.0 & 7.1 & 61.2 & 49.1 & 2.0 \\
\cline { 2 - 8 } & 140 & 61.5 & 37.9 & 10.1 & 59.3 & 51.1 & 2.4 \\
\cline { 2 - 8 } & 210 & 60.7 & 38.8 & 10.2 & 57.5 & 52.0 & 3.4 \\
\hline
\end{tabular}

L- leguminous plants; G - grasses; W - weeds

However, not all leguminous plants react in the same way to nitrogen fertilization. Reaction depends on the quantity of added nitrogen, as well as on the structure of the used mixture. Halling and Wallgren (1996), in their study of the mixtures of alfalfa and red clover with meadow fescue and timothy grass fertilized with 100 and $200 \mathrm{kgN} \mathrm{ha}^{-1}$, concluded that the share of red clover decreased in favour of grasses with the increase of the amount of nitrogen used, whereas the share of alfalfa increased. Balan et al. (2004), in the study of the fertilization of bird's foot trefoil with cocksfoot or tall fescue with $100 \mathrm{kgN} \mathrm{ha}^{-1}$ concluded that the share of bird's foot trefoil in mixture with cocksfoot decreased from $45.5 \%$ to $7.5 \%$ when fertilized with $100 \mathrm{kgN} \mathrm{ha}^{-1}$, and in mixture with tall fescue from $61.5 \%$ to $33 \%$. Kohoutek et al. (2004) in their study of the mixtures of red and white clover with cocksfoot and tall fescue concluded that the fertilization resulted in decrease of share of clovers in mixture with cocksfoot, but not in the mixture with tall fescue.

The decrease of the leguminous component in grassland due to fertilization with $\mathrm{n}$ is explained by decreased nitrogen fixation and poorer use of mineral $\mathrm{N}$ from soil compared to grass component (Frankow-Lindberg, 1987; Stout et al., 2001). After the decrease, plants start to use $\mathrm{N}$ from soil, but if leguminous plants are cultivated with more competitive grasses, the available $\mathrm{N}$ is not enough for development and growth and they start to decrease their share in mixture.

In order for the structural composition of the mixture to remain unchanged, lower quantities of $\mathrm{N}$ should be applied in fertilization since they don't have the depressive impact or lead to minimum changes in shares of certain species.

\section{Production of dry matter of grass-leguminous mixtures}

Mineral and organic fertilizers today represent and invaluable tool for increasing of the yield of grown crops. Plants have large requirements for $\mathrm{N}$, therefore they need to be well provided with this nutrient during vegetation. Especially large quantities of nitrogen are accumulated by plants of large vegetative mass (Vojin et al., 2003). 
Application of $\mathrm{N}$ fertilizer in crops of grass-leguminous mixtures leads to increase of yield of green mass and dry matter. In the study of the effects of complex mineral fertilizers with 0,90 and $180 \mathrm{kgN} \mathrm{ha}^{-1}$ on yield of mixture of festulolium hybrid, English ryegrass, red and white clover of grassland, Komarek et al. (2007) concluded that the application of $\mathrm{N}$ fertilizer in the amount of $90 \mathrm{kgN}$ ha $^{-}$ ${ }^{1}$ resulted in increase of yield of grassland from 6.72 to $8.61 \mathrm{t} \mathrm{ha}^{-1}$, and adding of $180 \mathrm{kgN} \mathrm{ha}^{-1}$ even to $9.75 \mathrm{t} \mathrm{ha}^{-1}$. Also, Nešić (2006), Nešić et al. (2007b) and Bijelić (2009) established that fertilizing of alfalfa mixtures with cocksfoot, tall fescue and sainfoin with $\mathrm{n}$ fertilizers in the amounts of $0,70,140,210 \mathrm{kgN} \mathrm{ha}^{-1}$ resulted in gradual increase of the DM yield of the grassland.

Table 2. Yield of dry matter of grass-leguminous mixtures depending on the fertilization with different $N$ quantities in the period 2003-2007 (Source Nešić, 2006, Nešić et al., 2007b, and Bijelić, 2009)

\begin{tabular}{|c|c|c|c|c|c|c|c|c|c|c|c|c|c|c|c|c|c|c|c|c|}
\hline \multirow{3}{*}{ Mixt } & \multicolumn{20}{|c|}{$\mathrm{N} \mathrm{kg} \mathrm{ha}^{-1}$} \\
\hline & \multicolumn{5}{|c|}{ control } & \multicolumn{5}{|c|}{$70 \mathrm{~N}$} & \multicolumn{5}{|c|}{$140 \mathrm{~N}$} & \multicolumn{5}{|c|}{$210 \mathrm{~N}$} \\
\hline & '03 & ’04 & '05 & ’06 & '07 & '03 & '04 & '05 & ’06 & ’07 & '03 & ’04 & ’05 & '06 & '07 & '03 & '04 & '05 & ’06 & ’07 \\
\hline L & 6.9 & 14.6 & 9.5 & 9.4 & 9.5 & 7.5 & 15.7 & 11.3 & 10.6 & 11.3 & 7.4 & 17.0 & 10.1 & 9.9 & 10.3 & 5.4 & 16.3 & 10.7 & 11.9 & 11.6 \\
\hline $\mathrm{S} 1$ & 5.8 & 13.7 & 10.5 & 9.4 & 8.6 & 5.2 & 13.7 & 11.4 & 8.6 & 9.2 & 5.3 & 13.7 & 10.2 & 9.4 & 8.8 & 4.8 & 14.2 & 10.4 & 10.0 & 10.5 \\
\hline $\mathrm{S} 2$ & 4.6 & 13.4 & 9.6 & 8.5 & 8.5 & 4.5 & 14.4 & 9.2 & 8.9 & 8.8 & 5.2 & 16.5 & 10.3 & 9.2 & 9.3 & 4.7 & 17.6 & 10.3 & 10.6 & 10.5 \\
\hline S3 & 5.5 & 13.1 & 9.4 & 8.2 & 7.9 & 4.9 & 15.1 & 9.3 & 9.3 & 9.5 & 4.4 & 14.2 & 9.1 & 10.5 & 8.5 & 4.1 & 17.2 & 11.2 & 10.0 & 8.5 \\
\hline
\end{tabular}

S1-mixture of alfalfa and cocksfoot; S2- mixture of alfalfa, cocksfoot and tall fescue; S3- mixture of alfalfa, cocksfoot, tall fescue and sainfoin; L-alfalfa

Necessary quantities of nitrogen from fertilizer must be in accordance with the plant requirements. If these amounts exceed the requirements, they can have adverse effect i.e. result in the decrease of yield. Laidlaw (1984) investigated the effect of nitrogen fertilization $\left(0,30,60\right.$ and $\left.90 \mathrm{~kg} \mathrm{ha}^{-1}\right)$ on yield of dry matter of mixtures of four cultivars of white clover and English ryegrass in five year period. Total one year yield of dry matter showed no significant variations in the first three years of investigation, but in the fourth and fifth year, yield gradually decreased in average by 1.5-2.0 $\mathrm{t} \mathrm{ha}^{-1}$. Also, Razec et al. (2002) established that adding of nitrogen to mixtures in the quantities of 50 and $100 \mathrm{~kg} \mathrm{ha}^{-1}$ resulted in decrease of yield.

The effect of $\mathrm{N}$ application is not always the same and depends on agroclimatic conditions and presence of species in the mixture, i.e. reaction of certain species on applied amounts of nitrogen. Suleyman (2003), in a three year study of the DM yield in conditions without fertilization of alfalfa, sainfoin and their mixtures, established that the effect of fertilization was greater in alfalfa and its mixtures compared to sainfoin. Increase of yield in alfalfa was $32.4 \%$, of grasses in 
mixture with alfalfa $25.3 \%$, whereas in case of sainfoin the increase was in average $6.4 \%$, and in case of grasses in mixtures with sainfoin $34.2 \%$.

Leguminous plants as nitrogen-fixing plants provide for them selves the necessary $\mathrm{N}$ for normal growth and development. In the mixture, they pass a part of fixed nitrogen to associated grasses. According to some authors, the amount of $\mathrm{N}$ which grasses receive from nitrogen fixation is from $10 \%$ (Gebhart et al., 1993), to $80 \%$ of total nitrogen (Berdahl et al., 2001). However, adding of $\mathrm{N}$ mineral fertilizers to crops, in general leads to reduction of nitrogen fixation (Adamovich and Adamovicha, 2003), so the efficiency of utilization of $\mathrm{N}$ from nitrogen fixation as well as from other mineral fertilizers, necessary for forming of the DM yield of grassland, is different and depends on the amount of added mineral nitrogen. Mixture with equal shares of species, fertilized with $50 \mathrm{kgN} \mathrm{ha}^{-1}$ resulted in yields from $14.8 \mathrm{t} \mathrm{ha}^{-1} \mathrm{DM}$, fertilized with $150 \mathrm{kgN} \mathrm{ha}^{-1}, 16 \mathrm{t} \mathrm{ha}^{-1}$, and with the highest amount of nitrogen - $450 \mathrm{~kg} \mathrm{ha}^{-1}$ yield recorded was $17.7 \mathrm{t} \mathrm{ha}^{-1}$. Efficiency of nitrogen utilization for forming of $1 \mathrm{~kg}$ of dry matter was the highest in treatment with $50 \mathrm{kgN} \mathrm{ha}^{-1}$, with $1 \mathrm{~kg}$ of $\mathrm{N}$ yield of $261.2 \mathrm{~kg}$ DM was realized, and in case of fertilization with $450 \mathrm{kgN} \mathrm{ha}^{-1}$, with $1 \mathrm{~kg} \mathrm{~N} 41.2 \mathrm{~kg} \mathrm{DM}$ was formed (Nyfeler et al., 2008).

However, because of nitrogen fixation abilities of leguminous plants, the amounts of mineral nitrogen necessary for realization of certain forage yield of grasslands are significantly reduced. In numerous studies, it was proven that yield of mixtures without fertilization realized identical if not higher yield compared to pure crops fertilized with certain nitrogen quantities.

Malhi et al. (2002), studied the pure brome grass and alfalfa crops and their mixtures in different ratios $(2: 1 ; 1: 1 ; 1: 2)$ and five fertilization levels $(0,50$, 100,150 and $200 \mathrm{~kg} \mathrm{ha}^{-1} \mathrm{~N}$ ) and established that the yield of dry matter of pure grass crops was directly dependant on the amount of added nitrogen. Addition of $50 \mathrm{~kg} \mathrm{ha}^{-1}$ of nitrogen resulted in increase of yield by $75 \%$, and addition of $200 \mathrm{~kg}$ $\mathrm{ha}^{-1}$ of nitrogen by $255 \%$. Mixtures without fertilization, compared to pure grass crops, gave yields that were the same as yields of pure grass crops fertilized with $150 \mathrm{~kg} \mathrm{ha}^{-1} \mathrm{~N}$.

In the study of the pure English ryegrass crop fertilized with 0, 100, 200, 300 and $400 \mathrm{~kg} \mathrm{ha}^{-1}$ of nitrogen, and mixtures of alfalfa and cocksfoot and red clover and English ryegrass without fertilization, Deprez et al. (2004) concluded that mixtures realized similar yield as pure grass crops fertilized with $400 \mathrm{~kg} \mathrm{ha}^{-1}$ N. Pure English ryegrass crop fertilized with maximum amount of nitrogen realized yield of 11.5-16.5 tha ${ }^{-1}$, and mixture without fertilization, alfalfa and cocksfoot 11.6-14.0 $\mathrm{t} \mathrm{ha}^{-1}$, and red clover with English ryegrass - 12.3-15.1 $\mathrm{t} \mathrm{ha}^{-1}$.

In numerous researches it was determined that yields of grass-leguminous mixtures did not deviate, and in some cases even exceeded, yields of pure crops of leguminous plants and grasses, which fully justified their cultivation. Also, contrary to pure grass crops, which require heavy $\mathrm{N}$ fertilization, high yields in 
mixtures can be realized with use of significantly smaller amounts of $\mathrm{N}$, which makes this production considerably more efficient.

Nitrogen fertilizers, in general, increase the dry matter yield of grasslands. However, efficiency of the application is significantly higher when lower amounts of nitrogen fertilizer are added. This shows that high productivity in the intensive production system could be realized by use of grass-leguminous mixtures fertilized with lower amounts of nitrogen resulting in huge savings of $\mathrm{N}$ fertilizer which is the ultimate goal of profitable and successful production.

\section{Quality of grass-leguminous mixtures}

In addition to providing of higher yield of green mass and dry matter compared to pure grass crops, mixtures also give better quality of the forage (Zimkova et al., 2002). Nutritional value of forage plants is determined based on the share of crude proteins, crude fibre, crude fats, crude ash and nitrogen free extracts (NFE), digestible and indigestible components of crude fibre as energy indicators. In case of utilization of high amounts of nitrogen fertilizers, very important indicator of the forage quality is nitrate content. The quality of forage is inversely proportional to yield, so $\mathrm{N}$ fertilizers used to increase yield of forage plants have depressive effect on the quality. According to Jeremić and Stošić (1981) fertilization of alfalfa and meadow fescue mixtures with NPK fertilizers in the amount of up to $90 \mathrm{~kg} \mathrm{ha}^{-1}$ results in the increase of crude proteins. Further adding of $\mathrm{N}$ from mineral fertilizers leads to decrease of $\mathrm{CP}$ content which can be explained by decrease of share of leguminous plants in the mixture (Berdahl et al., 2004).

In most researches it is explained that $\mathrm{N}$ fertilization leads to significant increase of CP content, such as study by Kitczak (1997) who states that the amount of nitrogen of $150 \mathrm{~kg} \mathrm{ha}^{-1}$ increases the CP content up to $29 \%$, Komarek et al. (2007) states that in treatments with the highest amount of nitrogen of $180 \mathrm{~kg} \mathrm{ha}^{-1}$, $\mathrm{CP}$ content increased from 120.6 to $134.6 \mathrm{~g} \mathrm{~kg}^{-1} \mathrm{DM}$. Gradual adding of $\mathrm{N}$ to alfalfa mixtures with cocksfoot, tall fescue and sainfoin, in the amounts of 0,70 , 140 and $210 \mathrm{kgN}$ ha, resulted in gradual increase of CP content in dry matter of the grassland (Bijelić, 2009). 


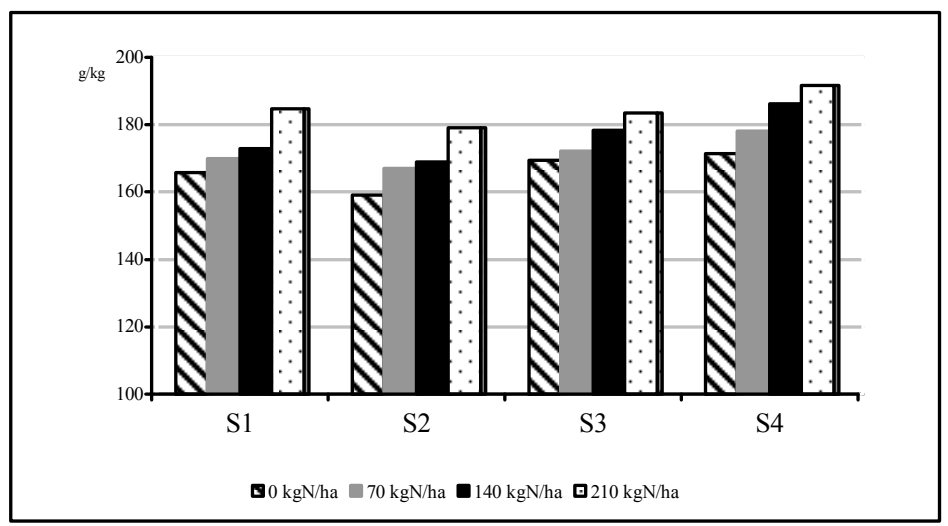

Graph 2. Average content of crude proteins in dry matter of grass-leguminous mixtures and alfalfa depending on the structure of mixture and nitrogen fertilization during three year research period (Source: Bijelić, 2009)

In addition to increase of the $\mathrm{CP}$ content, $\mathrm{n}$ fertilization also has favourable influence on yield of proteins, Stringer et al. (1996) states in his studies that N fertilization significantly increases the yield of $\mathrm{CP}$ in alfalfa mixture in average by $0.83 \mathrm{kgCP} \mathrm{kg}^{-1} \mathrm{~N}$.

Other parameters of the forage quality under the influence of fertilization, contrary to protein content, decreased or remained at the same level. In the mixture of bird's foot trefoil and cocksfoot, under the influence of $\mathrm{N}$ fertilization the NFE content decreased by $13.17 \%$, whereas the content of fibre remained unchanged (Ocokoljić et al., 1984). Also, Stringer et al. (1996) established that the fertilization of mixture reduced the content of crude fibre by $11-16 \mathrm{~g} \mathrm{~kg}^{-1}$. In the research by Bijelic (2009), NFE content increased with the addition of nitrogen in the amount of $70 \mathrm{~kg} \mathrm{ha}^{-1}$. Further adding of nitrogen resulted in decrease of NFE content, which is explained as the consequence of increase of CP content (Akdeniz et al., 2006).

Content of crude fats and mineral substances show no great dependence of the $\mathrm{N}$ fertilization (Bijelić, 2009). However, there are studies showing that the content of crude fats increases with adding of $\mathrm{N}$ (Vučković et al., 2005).

NDF in plants represents the amount of cellulose, hemicellulose, lignin and insoluble substances, and is indicator of readily consumed food fibre (Fahey and Berger, 1988). Numerous authors have studied the effect of $\mathrm{N}$ fertilizers on content of NDF in plants and concluded that the NDF content in plants increased significantly with adding of $\mathrm{N}$ fertilizer, which is explained as consequence of changes in the botanical composition of the grassland, i.e. decrease in the share of leguminous plants, and increase of share of grasses occurring as result of addition of N (Kopp et al., 2003, Berdahl et al., 2004, Salis and Vargiu, 2008). ADF as measure of the energy value of plants does not change significantly under the 
influence of N fertilization (Kopp et al., 2003; Knežević et al., 2007; Salis and Vargiu, 2008).

However, there are researches where $\mathrm{N}$ from fertilizer shows no significant effect on increase of NDF content (Knežević et al., 2007), but has significant effect on increase of ADF content in animal food (Keady et al., 2000).

Table 3. Neutral detergent fibre and acid detergent fibre (\% DM) of alfalfa-meadow brome grass (A) and meadow brome grass (G) pastures in fertilized (F) and unfertilized (U) conditions (1995-1997) (Source Kopp et al., 2003)

\begin{tabular}{|c|c|c|c|c|}
\hline \multirow{3}{*}{ year } & \multicolumn{4}{|c|}{ Treatment } \\
\hline & \multicolumn{2}{|c|}{ NDF } & \multicolumn{2}{|c|}{ ADF } \\
\hline & $\mathrm{AF}$ & AU & $\mathrm{AF}$ & AU \\
\hline \multirow{2}{*}{1995} & $50.5 \mathrm{~b}$ & $49.4 b$ & $36.9 \mathrm{~b}$ & $37.1 \mathrm{~b}$ \\
\hline & $59.2 \mathrm{~b}$ & $56.2 \mathrm{c}$ & 45.2 & 43.5 \\
\hline \multirow{2}{*}{1996} & $60.2 \mathrm{~b}$ & $57.5 b$ & 39.3 & 38.3 \\
\hline & $60.1 \mathrm{~b}$ & $58.5 b$ & $41.4 \mathrm{~b}$ & $43.0 \mathrm{~b}$ \\
\hline \multirow{3}{*}{1997} & $48.1 \mathrm{c}$ & $46.6 \mathrm{c}$ & $28.4 b$ & $29.0 \mathrm{~b}$ \\
\hline & $51.3 \mathrm{c}$ & $49.3 c$ & $33.5 \mathrm{c}$ & $32.8 \mathrm{c}$ \\
\hline & 60.8 & 62.2 & $36.3 b c$ & $38.9 \mathrm{ab}$ \\
\hline \multirow{2}{*}{ 3-yr. avg } & $53.0 \mathrm{c}$ & $51.2 \mathrm{~d}$ & $34.9 \mathrm{c}$ & $34.8 \mathrm{c}$ \\
\hline & $56.4 \mathrm{c}$ & $53.6 \mathrm{~d}$ & $39.7 b$ & $39.2 \mathrm{~b}$ \\
\hline
\end{tabular}

AF-alfalfa and brome grass + fertilization; AU- alfalfa and brome grass + no fertilization

Quality of animal food can be expressed also through adequate energy fractions for different animal species. Major energy indicator of the quality of food for ruminants is net energy for lactation and fattening/production of meat (NEL and NEM) i.e. energy ratio in diet available for production of milk or meat. Kohoutek et al. (2008) studied the effect of different levels of fertilization by complex NPK fertilizers on forage quality of natural grasslands in Central Europe and concluded that the NEL and NEM content increased significantly with the increase of the amount of added nitrogen. Štýbnarová et al. (2010) obtained similar results in their study.

Table 4. Forage quality of grasslands at different levels of fertilization (Source Kohoutek et al., 2008)

\begin{tabular}{|l|c|c|c|c|}
\hline $\begin{array}{l}\text { Treatments of } \\
\text { fertilization }\end{array}$ & \multicolumn{1}{c}{$\begin{array}{c}\mathrm{CP} \\
\left(\mathrm{g} \mathrm{kg}^{-1} \mathrm{DM}\right)\end{array}$} & \multicolumn{1}{c}{$\begin{array}{c}\text { Fibre } \\
\left(\mathrm{g} \mathrm{kg}^{-1} \mathrm{DM}\right)\end{array}$} & $\begin{array}{c}\text { NEL } \\
\left(\mathrm{MJ} \mathrm{kg}^{-1} \mathrm{DM}\right)\end{array}$ & $\begin{array}{c}\text { NEM } \\
\left(\mathrm{MJ} \mathrm{kg}^{-1} \mathrm{DM}\right)\end{array}$ \\
\hline F0 & 144.0 & 236.5 & 5.58 & 5.39 \\
\hline FPK & 141.5 & 247.8 & 5.46 & 5.24 \\
\hline FPKN90 & 139.3 & 260.6 & 5.35 & 5.15 \\
\hline FPKN180 & 151.9 & 262.2 & 5.36 & 5.17 \\
\hline AVERAGE & 144.3 & 251.8 & 5.44 & 5.24 \\
\hline DT0.05 & 2.8 & 2.9 & 0.03 & 0.06 \\
\hline DT0.01 & 3.4 & 3.6 & 0.04 & 0.07 \\
\hline
\end{tabular}

DT-Tukey test 
Contrary to these results, Postišek et al (2007) studied the effect of different levels of fertilization on quality of grassland forage, but concluded that there was no significant dependence between energy levels and levels of added $\mathrm{N}$.

Excessive application of nitrogen mineral fertilizers increases the amount of available in soil solution, which increases the adoption/intake of nitrates in plants and their accumulation in plant tissues. Nitrates $\left(\mathrm{NO}_{3}{ }^{-}\right)$, if present in excessive amounts in the plants, can cause poisoning of animals. Nitrate content in plant material becomes potentially dangerous when nitrogen amounts increase and exceed the amounts necessary for realization of satisfactory yield of dry matter (Nešić, 2006). Nitrate content varies from cut to cut depending on the type of crops and fertilization. In English ryegrass, maximum of nitrate intake is in the range of fertilization from 400 to $600 \mathrm{~kg} \mathrm{ha}^{-1}$, and in mixtures from 300 to $400 \mathrm{~kg} \mathrm{ha}^{-1}$. Maximum concentration of nitrates was registered in pure English ryegrass crop fertilized with $400 \mathrm{kgN} \mathrm{ha}^{-1}$ of $9345 \mathrm{mg} \mathrm{kg}^{-1} \mathrm{DM}$, and in mixture of white clover and English ryegrass fertilized with $300 \mathrm{kgN} \mathrm{ha}^{-1}$ of $6255 \mathrm{mg} \mathrm{kg}^{-1} \mathrm{DM}$, (Shiel et al., 1999).

Jeremić and Stošić (1981) established that in the mixture of alfalfa and meadow fescue (70:30) content of nitrate nitrogen increased with the increase of nitrogen dose in the food. With $30 \mathrm{kgN} \mathrm{ha}^{-1}$ content of $\mathrm{NO}_{3} \mathrm{~N}_{\text {was }} 19 \mathrm{mg} 100 \mathrm{~g}^{-1}$,

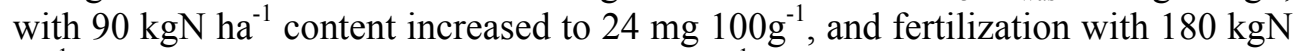
$\mathrm{ha}^{-1}$ resulted in content of $\mathrm{NO}_{3} \mathrm{~N}_{\text {of }} 30 \mathrm{mg} 100 \mathrm{~g}^{-1}$.

In the study of different quantities of mineral nitrogen on nitrate content in grass-leguminous mixtures, Nešić et al., (2008a), Nešić et al., (2008b) also concluded that with the increase of the amount of mineral nitrogen the nitrate content in plants increased, and it varied from 1190 to $3401 \mathrm{mg} \mathrm{kg}^{-1}$ (2003) and $732-2847 \mathrm{mg} \mathrm{kg}^{-1}$.

Table 5. Average content of $\mathrm{NO}_{3}^{-}\left(\mathrm{mg} \mathrm{kg}^{-1}\right)$ in $\mathrm{DM}$ of sown grassland depending on the sward type and $N$ fertilization over cuts in 2003 and 2004 (Source Nešić et al., 2008a, Nešić et al., 2008b)

\begin{tabular}{|c|c|c|c|c|c|c|}
\hline \multirow{2}{*}{ Year } & \multirow{2}{*}{$\begin{array}{c}\mathrm{N} \text { fertilization } \\
\left(\mathrm{kg} \mathrm{ha}^{-1}\right)\end{array}$} & \multicolumn{4}{|c|}{ Sward type } & \multirow[b]{2}{*}{ Average } \\
\hline & & Lucerne & Mixture I & Mixture II & Mixture III & \\
\hline \multirow{4}{*}{2003} & 0 & 1054 & 1175 & 1317 & 1215 & 1190 \\
\hline & 70 & 1694 & 1350 & 1939 & 1820 & 1701 \\
\hline & 140 & 1895 & 2808 & 2366 & 2227 & 2324 \\
\hline & 210 & 3055 & 3227 & 3812 & 3508 & 3401 \\
\hline \multirow[t]{4}{*}{2004} & 0 & 836 & 593 & 652 & 846 & 732 \\
\hline & 70 & 1271 & 1441 & 839 & 1300 & 1213 \\
\hline & 140 & 1875 & 2167 & 1698 & 2215 & 1989 \\
\hline & 210 & 2550 & 2972 & 2386 & 3479 & 2847 \\
\hline
\end{tabular}

Mixture I- alfalfa + orchard grass; Mixture II- alfalfa + orchard grass + tall fescue; Mixture III- alfalfa + orchard grass + tall fescue + sainfoin 
In literature, different data can be found on allowed concentrations of nitrate in animal food. If it is toxic to animals or not, depends not only on the concentration of $\mathrm{NO}_{3}^{-}$but also on health condition of animals, age, nutrition, exposure to stress and injuries (Wright and Davison, 1964 quote by MacKown and Weik, 2004). Republic of Serbia still is not regulating the amount of nitrates in animal food, but in Great Britain, Agronomy Research Council has confirmed in 1980 that concentrations of $3000-5000 \mathrm{mg} \mathrm{kg}^{-1} \mathrm{DM}$ are to be considered as potentially dangerous and avoided in certain groups of animals, such as gravid livestock because of the risk of abortion (quote by Shiel et al., 1999). In United States of America, there is wide spectrum of restrictions depending on the region. In some states the concentration of $<9000 \mathrm{mg} \mathrm{kg}^{-1}$ is considered as toxic to animals, and in other states concentration of $<15000 \mathrm{mg} \mathrm{kg} \mathrm{DM} \mathrm{(Hartwig} \mathrm{and} \mathrm{Barnhart,}$ 2001).

\section{Conclusion}

Application of $\mathrm{N}$ fertilizers in grass-leguminous mixtures leads to significant changes of production and qualitative properties of grasslands.

Changes of the botanical composition induced by application of $\mathrm{N}$ on crops are directed towards decrease of the leguminous component to the advantage of the grass component. Decrease of leguminous component as nitrogen fixing unit, the requirements of the grasslands for mineral nitrogen increase which increases the cost of production and reduces its sustainability. Therefore, lower quantities of $\mathrm{N}$ to compensate the needs after nitrogen fixation are the right decision.

Mineral fertilizers have favourable effect on yield of dry matter of grassland. However, excessive amounts can exhibit contrary effect. The effect of applied mineral fertilizers is always higher when lower quantities of $\mathrm{N}$ are applied which also has positive effect on economical efficiency and profitability of the production.

Of qualitative properties, the most pronounced is the effect of $\mathrm{N}$ on content and yield of crude proteins and content of nitrates. Content of $\mathrm{CP}$ and protein yield increased proportionally with the increase of applied nitrogen. Nitrate content in forage as unfavourable factor of quality also increased, especially if applied quantities exceeded the defined nitrogen requirements of plants. NDF content in plants, with the addition of $\mathrm{N}$, increases significantly, as consequence of changes in the botanical composition of the grassland. However, ADF content remains the same, mostly, although there are some studies showing the contrary. NEL and $\mathrm{NEM}$, as measures of the energy value of plants, increase with the $\mathrm{N}$ mineral fertilization. 
Grass-leguminous mixtures with adequate nitrogen fertilization have conditions for realization of high and stable yields of satisfactory quality. Fertilization with high amounts of nitrogen has favourable effect on yield of green mass and dry matter of grassland, content and yield of crude proteins, leads to accumulation of high quantities of nitrate in forage and changes intensively the structure of the mixture, by decreasing the leguminous component and favouring the grass component. Therefore, recommendations in practice relating to $n$ fertilization should be based on lower quantities of nitrogen.

\title{
Acknowledgment
}

Research was financed by the Ministry of Education and Science, Republic of Serbia, project TR-31053.

\section{Uticaj djubrenja azotom na proizvodne i kvalitativne osobine sejanih travnjaka u sistemu održive proizvodnje}

\author{
Z. Bijelić, Z. Tomić, D. Ružić-Muslić
}

\section{Rezime}

Azotofiksacijom u travno-leguminoznim smešama nije moguće zadovoljiti potrebe biljaka za azotom, pa je potrebno taj nedostatak nadoknaditi azotom iz mineralnih đubriva. Cilj ovog rada jeste da prikaže efekat primene $\mathrm{N}$ đubriva u travno leguminoznim smešama na njihove proizvodne i kvalitativne karakteristike, odnosno da da odgovor na pitanje da li upotrebom azotnih djubriva dolazi do povećanja ili smanjenja prinosa, kvaliteta kao i promena strukturnog sastava travnjaka. $\mathrm{N}$ iz mineralnih đubriva, naročito visoke količine azota, menjaju strukturni sastav travnjaka tako što smanjuju udeo leguminoza, a povećavaju udeo trava. Prinos suve materije se povećava dodavanjem azota đubrivima. Količine koje prevazilaze potrebe biljaka za azotom smanjuju ekonomsku opravdanost đubrenja i nekad mogu da imaju suprotan efekat. Đubrenje azotom povećava sadržaj sirovih proteina i prinos proteina, dok se ostali parametri kvaliteta smanjuju ili ostaju nepromenjeni. Prevelike količine azota u usevu dovode do nagomilavanja nitrata u biljkama kao nepoželjnog parametra kvaliteta. 


\section{References}

ADAMOVICH A., ADAMOVICHA O. (2003): Productivity and forage quality of Festulolium/legume mixed swards in response to cutting frequency. Grassland Science in Europe, 8, 453-456.

AKDENIZ H., KARSLI M.A., ÜLKER M., ORAL E. (2006): Effects of increasing levels of $\mathrm{N}$ fertilization on yealds and nutrition content of different barley varieties grown under arid condition. Journal of Animal and Veterinary Advences, 5, 2, 150155 .

ALIBEGOVIĆ-GRBIĆ S., ERIĆ P., VUČKOVIĆ S., ĆUPINA B., DUBLJEVIĆ R., IVANOVSKI P., PRENTOVIĆ T., GATARIĆ Đ., NEDOVIĆ B. (2005): Unapređenje proizvodnje krme na prirodnim travnjacima. Univerzitet u Sarajevu Poljoprivredni fakultet, 176.

BALAN M., BREAZU I., OPREA G. (2004): The productivity of cocksfoot and tall fescue in pure stand and in simple mixture with birdsfoot trefoil by varying nitrogen fertilization. Grassland Science in Europe, 9, 501-503.

BERDAHL J.D., KARU J.F., HENDRICKSON J.R. (2001): Dry matter yield of cool-seson Grass Monocultures and grass-alfalfa binary mixtures. Agronomy Journal, 93, 463-467.

BERDAHL J., KARN J., HENDRICKSON J. (2004): Nutritive quality of coolseason grass monocultures and binary grass-alfalfa mixtures at late harvest. Agronomy Journal, 96, 4, 951-955.

BIJELIĆ Z. (2009):Uticaj strukture smeše, đubrenja azotom i faze iskorišćavanja na parametre kvaliteta silaža travno-leguminoznih smeša. Doktorska teza, 1-146.

CASLER D.M., WALGENBACH R.P. (1990): Ground cover potential of forage grass cultivars mixed with alfalfa at divergent locations. Crop Science, 30, 825-831.

DEPREZ B., LAMBERT R., DECAMPS C., PEETERS A. (2004): Production and quality of red clover (Trifolium pratense) and lucerne (Medicago sativa) in pure stand or in grass mixture in Belgium. Grassland Science in Europe, 9, 498-500.

FAHEY G.C., BERGER L.L (1988): Carbohydrate nutrition of ruminants, 269-297.

FRAME J., LAIDLAW S.A. (1998): Managing white clover in mixed swards principles and practice. Pastos, XXVIII (1), 5-33.

FRANKOW-LINDBERG B.E. (1987): Lucerne grass swards with different nitrogen application and grass components. Swedish Journal of Agricultural Research, 17, 179-184.

GEBHART L.D., CALL A.C., WEAVER W.R. (1993): Dinitrogen fixation and transfer in legume-crested wheatgrass mixtures. Journal of Range Management, 46, 431-435.

HALLING A.M., WALLGREN B. (1996): Effect of harvest system and nitrogen rate on the performance of lucerne or red clover in mixtures with grass. EGF 96. HARTWIG N.R., BARNHART S.K. (2001): Nitrate toxicity. 
http://www.iowabeefcenter.org/content/newsrel/2001/701/nitrate toxicity.htm JERANYAMA P., LEEP R., DIETZ T., MIN D. (2005): Sward composition, forage yield and grazing effects in kure clover and grass mixtures. Proceeding of the XX international Grassland Congress, Dublin, Ireland, 530.

JEREMIĆ D. STOŠIĆ M. (1981): Proučavanje uticaja različitih nivoa azota u ishrani vrsta iz familije Fabaceae i Poaceae i njihovih smeša. Agrohemija, 11-12, 432-439.

KEADY T.W.J., MAYNE C.S., FITZPATRICK D.A. (2000): Prediction of silage feeding value from the analysis of the herbage at ensiling and effect of nitrogen fertilizer, date of harvest and additive treatment on grass silage composition. Journal of Agricultural Science, Cambridge, 134,353-368.

KITCZAK T. (1997): Plonowanie lucerny (Medicago sativa) siewnej i stoklosy obiedkowatej (Bromegrass unioloides) w seiwe czystym i mieszanym w warunkach zroznicowanego nawozenia azotowego i nawadniania. Biul. Oceny Odm., 29, 167-172.

KNEŽEVIĆ M., LETO J., PERČULIJA G., BOŠNJAK K., VRANIĆ M. (2007): Effect of liquid manure application on yield quality and botanical composition of grassland. VI. Alps-Adria Scientific Workshop, Obervellach, Austria, 637-640.

KOHOUTEK A., ODSTRČILOVA V., KOMAREK P., NERUŠIL P. (2004): Persistance and production ability of Dactylis glomerata, Festuca arundinacea and genus hybrids in 1986-2003. Grassland Science in Europe, 9, 422-424.

KOHOUTEK A., KOMAREK P., NERUŠIL P., ODSTRČILOVA V., HRABE F., ROSICKA L., ŠRAMEK P., KAŠPAROVA J., GAISLER J., FIALA J., POZDIŠEK J., MIČOVA P., SVOZILOVA M., JAKEŠOVA H. (2008): Effects of intensity of fertilization and cutting frequency on forage quality and diversity of permanent grassland in Central Europe in 2003-2007. Grassland Science in Europe, 13, 595-597.

KOMAREK P., NERUŠIL P., KOHOUTEK A., ODSTRČILOVA V. (2007): The effect of repeted direct sowing of grass-legume seed mixtures into grasslands on forage production and quality. Grassland Science in Europa, 12, 39-42.

KOPP J.C., MCCAUGHEY W.P., WITTENBERG K.M. (2003): Yield, quality and cost effectiveness of using fertilizer and/or alfalfa to improve meadow bromegrass pastures. Can. J. Anim. Sci., 83, 291-298.

LAIDLAW A.S. (1984): Quantifying the effect of nitrogen fertilizer applications in spring on white clover content in perennial ryegrass-white clover swards. Grass and Forage Science,39,317-321.

MALHI S.S., ZENTNER R.P., HEIER K. (2002): Effectiveness of alfalfa in reducing fertilizer $\mathrm{N}$ input for optimum forage yield, protein concentration, returns and energy performance of bromegrass-alfalfa mixtures. Nutrient Cycling in Agroecosystems, 62, 219-227. 
MIJATOVIĆ M., PAVEŠIĆ-POPOVIĆ J., KATIĆ S. (1983): Gajenje travnih i travno-leguminoznih smeša na oranicama brdskog područja. Zbornik radova, IV jugoslovenski simpozijum o krmnom bilju, Novi Sad, 180-186.

NEŠIĆ, Z. (2006): Uticaj đubrenja azotom i udela lucerke na prinos i kvalitet krme sejanog travnjaka. Magistarska teza, 1-100.

NEŠIĆ Z., TOMIĆ Z., VUČKOVIĆ S., KRNJAJA V., JOSIPOVIĆ S., RUŽIĆMUSLIĆ D. (2007a): Promene botaničkog sastava lucerkinih smeša u zavisnosti od vrsta u smeši i djubrenja N. Biotechnology in Animal Husbandry, 23, 5-6, 2, 365-374.

NEŠIĆ Z., TOMIĆ Z., VUČKOVIĆ S., RUŽIĆ-MUSLIĆ D. (2007b): Prinos travno-leguminoznih smeša u zavisnosti od botanickog sastava i djubrenja azotom. Zbornik radova instituta za ratarstvo i povrtarstvo, 44, 375-379.

NEŠIĆ Z., TOMIĆ Z., RUŽIĆ-MUSLIĆ D.,VUČKOVIĆ S. (2008a): Effects of seed mixture and $\mathrm{N}$ fertilization on nitrate content of grass-legume swards. Grassland Science in Europe, 13, 429-431.

NEŠIĆ Z., TOMIĆ Z., KRNJAJA V., TOMAŠEVIĆ D. (2008b): Nitrates in Plants and Soil After Fertilizarion of Grass-legume Mixtures. Biotechnology in Animal Husbandry, 24, 5-6, 95-104.

NYFELER D., HUGUENIN-ELIE O., SUTER M., FROSSARD E., LUSCHER A. (2008): Well-balanced grass-legume mixtures with low nitrogen fertilization can be as productive as highly fertilized grass monoculture. Grassland Science in Europe, 13, 197-199.

NUTTALL W.F., MCCARTNEY D.H., BITTMAN S., HORTON P.R., WADDINGTON J. (1991): The effect of N, P, S fertilizer, temperature, and precipitation on the yield of bromegrass and alfalfa pasture established on a Luvisolic soil. Canadian Journal of Plant Science, 71, 1047-1055.

OCOKOLJIĆ S., VELIČKOVIĆ G., PARIS Z., NINKOVIĆ S. (1984): Uticaj različitih nivoa đubrenja azotnim i NPK đubrivima na prinos, botanički i hemijski sastav i sadržaj nekih važnijih aminokiselina kod smeše ježevice (Dactylis glomerata) i žutog zvezdana (Lotus corniculatus). Agrohemija, 4, 265-274.

POZDÍŠEK J., ŠTÝBNAROVÁ M., SVOZILOVÁ M., LÁTAL O. (2007): Changes in chemical composition, digestibility and energy content in permanent grassland influenced by intensity of utilization and fertilization. Grassland Science in Europe, 12, 70-73.

RAZEC M., RAZEC I., CHIPER C., OPREA G. (2002): Yield and quality forage improvement by N-use efficiencyin grass-cliver sward. Grassland Science in Europe, 7, 154-155.

SALIS L., VARGIU M. (2008): Influence of mineral fertilization on production and quality of forage in a Sardinian pasture. Grassland Science in Europe, 13, 308-310. SHIEL R.S., TILIB A.B.A., YOUNGER A. (1999): The influence of fertilizer nitrogen, white clover content and environmental factors on the nitrate content of 
perennial ryegrass and ryegrass/white clover swards. Grass and Forage Science, 54, 275-285.

STOUT W.L., WEAVER S.R., ELWINGER G.F. (2001): Effects of early season nitrogen on grass -clover swards in the Northeastern Usa. Agronomy Journal, 93, 1000-1005.

STRINGER W.C., MORTON B.C., PINKERTON B.W. (1996): Row spacing and nitrogen: Effect on alfalfa - bermudagrass quality components. Agronomy Journal, 88, 573-577.

ŠTÝBNAROVÁ M., SVOZILOVÁ M., HAKL J., KARABCOVÁ H., POZDÍŠEK J., OTRHÁLKOVÁ P. (2010): Effect of different management on the yields, forage quality and botanical composition of permanent grassland. Grassland Science in Europe, 15, 741-743.

SULEYMAN S. (2003): Performance of some forage grasses or legumes and their mixtures under dry land conditions. European Journal of Agronomy, 19, 401-409.

VOJIN S., ERIĆ P., UBAVIĆ M. (2003): Ishrana biljaka i đubrenje, Poljoprivredni institut, Banja Luka. 169.

VUČKOVIĆ S. (2004): Travnjaci. Poljoprivredni fakultet- Univerzitet u Beogradu, 488. VUČKOVIĆ S., SIMIĆ A., ĐORĐEVIĆ N., ŽIVANOVIĆ T., STOJANOVIĆ I., STANISAVLJEVIĆ R. (2005): Effect of nitrogen fertilizer and underseeding on the productivity and chemical composition of Cynosuretum cristati type meadows on hilly-mountainous grassland in Serbia. Grassland Science in Europe, 10, 489-492.

WRIGHT M.J., DAVISON K.L. (1964): Nitrate accumulation in crops and nitrate poisoning in animals. Adv. Agron., 16, 197-247. In: MACKOWN C.T., WEIK, J. C. (2004): Comparison of laboratory and quick-test methods for forage nitrate. Crop Science, 44, 218-226.

YOLCU H., SERIN Y., TAN M. (2010): The effects of seeding patterns, nitrogen and phosphorus fertilizations on production and botanical composition in lucernesmooth bromegrass mixtures. Bulgarian Journal of Agricultural Science, 16, 6, 719-727.

ZIMKOVA M., TISLIAR E., MICHALEC M. (2002): Chemical and botanical composition of grass-legume mixtures in relationship to soil chemical composition. Grassland Science in Europe, 7, 102-103. 